\title{
The Non-Governmental University Party Construction Innovation \\ Research and Practice Research
}

\author{
Liangxi Ding ${ }^{1, a}$ \\ ${ }^{1}$ Nanchang Institute of Technology, Nanchang, Jiangxi, 330044
}

\begin{abstract}
Keyword. Non-government University, Party Construction, Innovation Research
\end{abstract}
\begin{abstract}
The non-governmental university party construction" is an important component of the non-governmental university party construction work, is also an important part of moral education in colleges and universities. This paper studies the background of the party construction and the main method to this current situation.
\end{abstract}

\section{Introduction}

"Two learn how to make a" is the party's mass line education practice, after "three steady tightening real" special education, deepen the party is an important practice of education is to promote learning education from "key a few" to all party members, from centralized education activities to the regular education of the important measures. "Two learn how to make a" learning pedagogy is a foundation, is the key. "Private colleges is to train high quality applied talents of the important position, private colleges to strengthen and improve party building work, is the implementation of the national high-skilled personnel training plan, train and bring up hundreds of millions of high-quality workers need; is to enhance the party's class foundation and expand its mass base, and constantly improve the party in the influence and cohesion of the whole society's major initiatives, is to strengthen the party's leadership in colleges and universities, the effective ways to comprehensively strengthen higher vocational students' ideological and political work. How to strengthen the private colleges students' party construction at the grass-roots level, cultivate not only scientific cultural quality and operating ability of students, and the political quality of applied talents, an important goal of colleges' basic level party is run by the local workers. Private colleges according to its own characteristics and requirements to strengthen and improve the students' party construction, we need to seriously study, and have the courage to practice. Therefore, the study not only in a timely manner, and has very important theoretical and practical significance, the research at home and abroad are rare. The party, face is the party lead the development, to the party to promote the reform, ascend in party construction quality, to the party to achieve harmony, clots form hearts meet force training talents, coordinated development of the gratifying situation.

"The non-governmental university party construction" is an important component of the non-governmental university party construction work, is also an important part of moral education in colleges and universities, the main purpose is to enhance students' ideological and political quality and moral quality, help students to establish communist ideal and firm the correct world outlook, the outlook on life, values, and voluntary to serve the people. To carry out the party construction of college students 


\section{Completes the Non-Governmental University Party Building Work, Idea Innovation is the Premise}

With private college scale expands unceasingly, the rapidly increasing number of students, private colleges, especially those of middle schools promotes private private colleges, student party construction work of ideas: first, because the private colleges of school-running idea, talent training pattern different from public colleges, such as in a professional and pay more attention to applicability and practicability on the curriculum, training talents with technology is given priority to, this leads to widespread in private colleges "practical, thought, heavy technology, light party" the phenomenon, some private colleges too attaches importance to the cultivation of student's professional technical and practical ability, while ignoring the students' ideological and political education and the cultivation of party members and management, not enough emphasis on party construction work. Second, because until today in development of higher vocational education, but also on the strength of competition and become bigger and stronger, such as some people think that the number of students and the number of fixed assets is the hardware conditions, develop continuously, must grasp, and party building and ideological and political work is a long-term project, soft, soft data, can take your time. Party building and ideological and political work occurs when caught when put, yet too-loosely aligned phenomenon, to a certain extent affect the status and role of party construction and ideological and political work. Third, in terms of student party member development work, because of the restriction of the traditional work idea and mode, especially those of middle schools promotes private colleges, it is difficult to from the original several year development student party members to complete the student party member development work of system, the number of private colleges development of party members and student party member development work from there is the gap of the specific goals and requirements. Concept innovation, is to do a good job in the premise of the non-governmental university party construction work.

\section{Completes the Non-Governmental University Party Building Work, Ruling Ability is to Make Sure}

Private colleges the party's ruling ability, is mainly refers to the party organizations at all levels of private colleges and universities to carry out the party's theory, line, principles, policies and strategies, and lead the masses of teachers and students staff, teaching, and in accordance with the effective management of school affairs, achieve the established education teaching ability. Private colleges the main body of the party's ruling ability construction including the party committee, the party (always) branch, party members and composed of them as a whole. Survey found that private colleges the party's ruling ability construction, there are some drawbacks in the non-governmental university party organization leadership, political role as the core, and guarantee to strengthen monitoring role: first, the part of private colleges of leading cadres to strengthen the party's ruling ability construction of the importance of understanding does not reach the designated position, there is a utilitarian tendency in the development of the school, can't correctly handle the relationship between the party's construction and operation, or lacerate, opposite, or disparage party construction attaches great importance to the business work. Second, the part of the theory of the party member the leading cadre quality is not high, responsibility consciousness, overall situation consciousness, innovation consciousness is not strong, the lack of political acumen, away from the requirements of the socialist politician and educator to a considerable gap. Third, some private colleges of leading cadres to international and domestic situation, school, school to observe the profundity and 
foresight, especially for the school reform, development and stability as well as a variety of development opportunities of master degree is low, flexibility and ability to cope with the new situation, to meet new challenges are not there. Improve the non-governmental university party's ruling ability, is completes the non-governmental university party construction work.

Governing idea innovation. Get great progress in recent years, the vocational education in our country, but because of the higher vocational education starts late I work relatively weak basis, the relative lack of education resources, teaching facilities, teaching conditions are relatively poor, the teachers strength is weak, running mode, educational philosophy and law of higher vocational education. Performance on the party's own construction, these problems is the party's ruling ability also can not adapt to the situation development requirements. Run by the local party committee in colleges and universities need to establish scientific governing idea, value idea innovation, target innovation, system innovation and supervision mechanism, characteristics and advantages of gradually form school.

\section{Completes the Non-Governmental University Party Construction Work, the Organization Construction, Team Construction, System Construction is the Foundation}

The non-governmental university party construction organization construction, team construction, system construction in the following problems: the imperfection of the non-governmental university student party construction work system, system is not sound, its organizational system at present most is just a big framework, the most grass-roots organization has not been fully development and cultivating, part of the college students has not been established departmental level party branch, let alone establish a branch in class, the students' party branch work function is not perfect, work innovation is insufficient, lack of energy. Private colleges give priority to with part-time students party branch staff at present, private colleges generally fewer full-time party affairs staff, and work multifarious, peacetime seldom have time to ponder earnestly and to develop students' party construction, party construction lack of scientific management. With the increase of the absolute number, work to submit the application form for the students and to develop a target of the phenomenon of evaluation procedures not rigorous, lead to the development programs and other work become a mere formality, the student party members' advanced nature is not outstanding, the atmosphere of party construction is far worse than public colleges and universities.

\section{Completes the Non-Governmental University Party Construction Work, the Student Party Members' Development and Education, Management is the Key}

Private universities ideological and political work overall level is not high, the quality of the "two lessons" serious shortage of teachers and counselors, make the students ideological and political work is in a state of relative lag. Under the current admissions system, compared with the undergraduate course colleges and universities students, vocational students' overall quality is less, some students with no admission to the undergraduate course colleges and universities and lose confidence and fight, or along, or are not interested in political beliefs, or interests from reality, consider only learn professional knowledge to lay the foundation for future employment problem, the other will not be considered. In addition, the general party activists inspection need two years to turn to probationary party member, only a year students to join the party of probationary period. And, in fact, as there is no social experience, theory training is still in its infancy, lack of social practice experience of college students, it remains to be further studied in practice and improve their theoretical accomplishment, in just one year rush to join the party, its strength is not enough 


\section{Completes the Non-Governmental University Party Building Work, Position is Means}

The non-governmental university party building work from the work level, scope of work and working effect than undergraduate course colleges and universities, we should grasp the initiative, develops the students' party construction in new areas, increase the non-governmental university party construction pertinence and effectiveness.

To implement party construction work to the apartment, to the community, extends to the whole society. Arrangement of student party members as a student cadre, do "dormitory management assistant," junior "assistant teacher in charge," will the party's tenet with students actual life. The party branch activities out of the department, for the school; Out of school, geared to the needs of society. Such as the revolutionary tradition education organization members to visit the old revolutionary base areas; Activist organizations, party members and the party to participate in the youth volunteer service activities, serve the society, caring; Organization of party members to state-owned enterprises, private enterprises, foreign-funded enterprises to carry out the party construction survey, understand the new situation and new task faced by the party, strengthen the sense of mission and sense of responsibility. We also need to establish a fixed places, "the home of party members" to carry out the party members "Open Day" activity, strengthen the construction of the party member activities positions.

\section{Completes the Non-Governmental University Party Building Work, Demonstration Activities of Party Membership Is Dynamic}

Non-governmental university students party members in students proportion is not high, and because of the late student party member's education hasn't caught up with that part of the student party members is not really solve the problem of the party on thought, utilitarian factors exist in the motivation to the party, in the part of students have joined the party, there is also a ideal faith desalinate, the party the phenomenon of motivation is not pure. In addition, the basic-level party organization cohesive force, combat effectiveness and appeal needs to be strengthened. As a result of the party members' education and management mode, method, content also can not adapt to the new situation, some neglect of party member education and management, ideological and political work is weak, some activity form rigid, monotonous content, effect is poor, a small number of party members the ideal faith is not strong, party spirit, indifferent to the people, and the cutting edge exemplary role play is not obvious.At the same time, in the new century and new stage, private colleges according to its own characteristics and requirements to strengthen and improve the students' party construction, we need to seriously study, and have the courage to practice, the need to constantly explore new ideas, to adapt to the new situation.

\section{Acknowledgment}

This thesis is 2016 province college humanities and social science research project, project number: SZZX16077, project name: under the background of the "two learn how to make a" private colleges party class education innovation research, periodic series of research results.

\section{Reference}

[1] Dongping Yang, China education development report 2005 - education blue book, social sciences academic press, 2006, (3): 101-105

[2] Zhijian Duan, advancing with The Times to talk about education, changsha: hunan science and 
technology press, 2005(6): 23-29.

[3] Xuefeng Ji, Always follow the party's voice -- college students in the new century, hunan normal university press, 2003(3):159-163. 